(C) Arizona Board of Regents on behalf of the University of Arizona 2022. This is a work of the U.S. Government and is not subject to copyright protection in the United States. Outside of the United States, this is an Open Access article, distributed under the terms of the Creative Commons Attribution-NonCommercial-NoDerivatives licence (http://creativecommons.org/licenses/by-nc-nd/4.0/), which permits non-commercial re-use, distribution, and reproduction in any medium, provided the original work is unaltered and is properly cited. The written permission of Cambridge University Press must be obtained for commercial re-use or in order to create a derivative work.

\title{
LOCAL SPATIAL HETEROGENEITY OF HOLOCENE CARBON ACCUMULATION THROUGHOUT THE PEAT PROFILE OF AN OMBROTROPHIC NORTHERN MINNESOTA BOG - CORRIGENDUM
}

Karis J McFarlane • Paul J Hanson • Colleen M Iversen • Jana R Phillips • Deanne J Brice

https://doi.org/10.1017/RDC.2018.37, published by Cambridge University Press, 30 May 2018.

In the original publication of this article (McFarlane et al. 2018), an incorrect unit of measurement appeared in the abstract. The fourth sentence of the abstract should read as follows:

"The long-term apparent rate of carbon accumulation over the entire peat profile was $22 \pm 2 \mathrm{~g} \mathrm{C} \mathrm{m}^{-2} \mathrm{yr}^{-1}$."

The original article has been updated. The authors apologize for this error.

\section{REFERENCE}

McFarlane KJ, Hanson PJ, Iversen CM, Phillips JR, Brice DJ. 2018. Local spatial heterogeneity of Holocene carbon accumulation throughout the peat profile of an ombrotrophic northern Minnesota bog. Radiocarbon 60(3): 941-962. doi: 10.1017/RDC.2018.37. 